\title{
Eça de Queirós: mercado literário e classe social
}

Rodrigo do Prado Bittencourt ${ }^{1}$

\section{Contexto editorial da segunda metade do século XIX}

Ainda que pequeno com relação ao total da população, o número de leitores em Portugal nunca antes havia sido tão grande. O complexo processo histórico de expansão das escolas, diminuição do analfabetismo, barateamento dos livros, expansão do mercado editorial e de instituições ligadas à leitura (bibliotecas públicas, gabinetes de leitura, bibliotecas de associações sindicais ou sociais, novas instituições de ensino superior, etc.) gerou uma concentração de forças nunca antes colocadas a serviço da leitura e do livro; notadamente, o Estado centralizado e forte a disseminar salas de aula pelo país e o capital industrial a fazer do livro uma fonte de lucros para empresas cada vez maiores e mais poderosas. Falta, porém, outro elemento aí. Há um novo poder que se soma ao do dinheiro e ao do Estado e que será de extrema importância para o mercado literário: a imprensa.

Eça de Queirós, em A Capital! (começos de uma carreira), e antes dele Balzac, em Ilusions perdues, não apenas ressaltaram o poder da imprensa, mas também demonstraram a ligação entre ela e o mercado livreiro. Com diversos jornais sendo publicados diariamente; com a disseminação dos mais importantes por todo o país e com a penetração deste veículo de comunicação em todas as classes sociais, a imprensa se constitui como força poderosíssima. Basta uma crítica positiva para elevar um livro às alturas da glória e para fazê-lo "vender como água"; bem como basta uma breve análise de seus defeitos para condená-lo ao pó dos estoques das editoras e dos livreiros.

O próprio José Maria Eça de Queirós deve ser visto como exemplo de como a mercantilização tomou conta do campo literário. A correspondência pessoal do escritor demonstra como ele passou a vida toda em busca de dinheiro e como pensou nos aspetos comerciais de suas obras mais sérias e profundas artisticamente, bem como pensou em outras apenas para servirem meramente como fonte de renda. Exemplos de obras deste segundo tipo são o almanaque que elaborou, o Dicionário de milagres, que quis publicar, e seus artigos para a

Doutorando do Centro de Literatura Portuguesa da Faculdade de Letras da Universidade de Coimbra (UC), Coimbra, Portugal. E-mail: rodrigopbittencourt@gmail.com 
imprensa brasileira. Não que não houvesse qualidade nessas obras, mas certamente elas foram pensadas dentro de uma ótica comercial, que não foi tão presente num livro de quase mil páginas como Os maias.

A questão comercial influencia o próprio gênero artístico a ser tentado pelo escritor. N'A Capital!, Melchior afirma ser muito difícil arrumar um editor para um livro de versos, o que remete o leitor atento às dificuldades que Lucien de Rubempré encontrou em Paris para editar o seu. Mais ainda: ela chega a contaminar a imprensa, que não apenas "troca" artigos e "locais" por auxílio político e mesmo propriamente por dinheiro - como fica claro no romance balzaquiano Ilusions perdues - bem como passa a, como mostrou Eça e também Balzac, vender livros que lhe são enviados para serem lidos e comentados nas secções de crítica literária. N'A Capital!, Melchior venderá livros chegados ao "Século" como complementação de sua renda. Só Artur parece não perceber esse caráter capitalista cada vez mais forte da literatura e da crítica literária. Caráter este que se encontra presente mesmo quando se trata de obras "sérias" e de "qualidade artística", como explicitou Bourdieu:

\begin{abstract}
Doravante, trata-se de uma verdadeira subordinação estrutural, que se impõe de maneira muito desigual aos diferentes autores segundo sua posição no campo, e que se institui através de duas mediações principais: de um lado o mercado, cujas sanções ou sujeições se exercem sobre as empresas literárias, seja diretamente, através das cifras de venda, do número de recebimentos etc., seja indiretamente, através dos novos postos oferecidos pelo jornalismo, a edição, a ilustração e por todas as formas de literatura industrial; do outro lado as ligações duradouras, baseadas em afinidades de estilo de vida e de sistema de valores que, especialmente por intermédio dos salões, unem pelo menos uma parte dos escritores a certas frações da alta sociedade, e contribuem para orientar as generosidades do mecenato de Estado (Bourdieu, 1996, p. 65).
\end{abstract}

Uma das mais importantes mudanças apontadas na citação acima é a configuração da intelectualidade como classe relativamente independente, como corpo social autônomo. Tem-se, agora, mais liberdade para a produção cultural e uma carreira mais complexa, com mais possibilidades de desenvolvimento. Ainda que não seja uma liberdade e uma independência total. N’A Capital!, por exemplo, vê-se que o avô bisavô de Artur Corvelo era um poeta parasita, que vivia à custa do mecenato da aristocracia, ainda que, incoerentemente, pregasse sua derrubada quando longe de seus olhos. Já o protagonista desta obra não pode contar com o auxílio de nenhum protetor ou mecenas, mas é obrigado a afirmarse no campo artístico com suas próprias forças. 
Como bem ressaltou Bourdieu, o campo literário acentua cada vez mais a autonomia do autor, mas isso se combina com um isolamento que o deixa sem ter com quem contar e o lança numa acirrada competição com outros novatos e com autores já consagrados pelas instituições literárias (universidades, academias, publicações especializadas):

o processo que conduz à constituição de um campo é um processo de institucionalização da anomia ao fim do qual ninguém pode colocar-se como senhor e possuidor absoluto do nomos, do princípio de visão e de divisão legítimo (Bourdieu, 1996, p. 153).

Artur é um romântico e é como tal que tentará inserir-se no mercado literário. Ele não percebe que, ávido de novidades e em contato com as obras francesas, o público lisboeta já está cansado da repetição das já gastas fórmulas românticas. $\mathrm{O}$ avanço dos meios de comunicação e de transporte faz com que as novidades da literatura estrangeira cheguem cada vez mais rápido a Portugal. A imprensa contribui para criar o hábito da leitura diária e para divulgar os livros recentemente lançados. Com a produção em massa de uma vasta gama de obras leves e sem muita originalidade, a literatura, sobretudo na forma de romance, perde sua sacralidade e torna-se cada vez mais um produto a ser rapidamente consumido e substituído; os livros tornam-se descartáveis. É justamente esse dinamismo do mercado literário e este rebaixamento do valor do livro que assustam João da Ega e Carlos da Maia, que não se sentem confortáveis diante desta lógica burguesa e do aburguesamento de toda a sociedade lusitana.

Carlos da Maia e João da Ega têm uma visão negativa do campo, por isso não produzem suas obras pretensamente revolucionárias no âmbito da Ciência, da Literatura e da Crítica. Gonçalo pensa que o tema patriótico e seu próprio nome ilustre já serão o suficiente para atrair sobre si a fama de erudito e nacionalista, trazendo-lhe prestígio político; não se importando sequer se será de fato lido ou não. Ou seja, os três têm uma visão do campo literário português como pouco desenvolvido e autônomo. Artur o imagina de outra forma. É ele quem está errado!

Gonçalo foca num público bem específico: os círculos eruditos e influentes politicamente, capazes de o indicarem como candidato graças aos méritos de seu nome e de sua erudição. Carlos da Maia, por ter escrito artigos de Medicina e iniciado um livro dentro desta mesma área, não pode almejar como público 
senão os seus colegas de profissão e um ou outro diletante que se interesse pelo assunto. João da Ega que, antes de planejar o livro de viagens ( Fornadas da Ásia), a Revista de Portugal (em companhia de Carlos) e a sátira social (O Lodaçal), expôs a ideia de seu Memórias de um Átomo para seus colegas universitários, sempre demonstrou desejar o reconhecimento não do grande público, mas das elites intelectuais; o que bem se nota em seu desprezo pelo leitor comum, patente neste breve diálogo com Alencar:

\footnotetext{
O poeta foi amável também, um pouco de alto, passando os dedos no bigode:

1 Vai-se andando. E tu que fazes? Quando nos dás essas Memórias, homem?

2 Estou à espera que o país aprenda a ler (QUEIRós, 1945b, p. 108).
}

Se o desejo de conquistar o grande público acostumado com os romances folhetinescos e outras obras grosseiras poderia ser encarado como mesquinhez para alguém da posição social de Gonçalo Mendes Ramires, Carlos da Maia ou João da Ega, ele é visto como aceitável para um pequeno-burguês recém-saído das fileiras proletárias, como Artur. Tendo ascendido socialmente graças a uma herança, compreende-se que o jovem provinciano almeje uma ascensão ainda maior e faça da literatura um trampolim para sua vitória. Aos aristocratas bem educados, no entanto, não se consente que a arte seja tratada como um mero instrumento de enriquecimento.

Assim, Gonçalo, que também espera enriquecer-se, deseja usar da arte não para conseguir dinheiro, mas, sim, prestígio. Ele pensa que, só após a conquista deste, obterá sucesso político e, portanto, dinheiro. Ou seja, para o fidalgo mais antigo de Portugal, o caminho que leva a arte a traduzir-se em dinheiro é mais longo e complexo, passando pelo prestígio. Bem à maneira descrita por Bourdieu (1996) para explicar a relação entre reconhecimento artístico e a acumulação monetária; com a diferença, porém, que Gonçalo conquista prestígio político e o traduz em votos e, por conseguinte, em dinheiro, enquanto os artistas consagrados transformam prestígio no seio do seu próprio campo de atuação - capital cultural - em valores pecuniários. Transformação que é demorada, pois demanda um considerável tempo de acumulação de prestígio literário para produzir alguma soma financeira vultosa.

Artur insere-se numa lógica mais rápida. É verdade que ele almeja também ser aceito pelo público mais erudito e refinado, em sua ambição desmesurada, mas Artur sempre sonhou com um sucesso massivo e imediato. Tanto é que, 
ao ver seu livro publicado, passa a prestar atenção nas conversas das pessoas à sua volta, certo de que comentam suas poesias e o veneram, como se toda a Lisboa o tivesse lido e apreciado sobejamente. No entanto, Artur falha por querer vender um produto que já não faz mais sucesso; já muito gozado e aproveitado, mas agora sem serventia.

O caso de Carlos da Maia e João da Ega difere muito do de Artur. Se o jovem provinciano não tinha quase nada a perder em tentar iniciar sua carreira literária, eles têm muito. Os dois jovens têm imensa fortuna, sobretudo Carlos da Maia, famílias de tradição aristocrática em suas origens, uma educação esmerada (nomeadamente a de Carlos, que envolveu concepções inglesas de Educação, o levou à Coimbra com conforto e luxo e ainda foi complementada por um longo período de viagens pelo mundo, que se estendeu até a longínqua Rússia), possibilidade de arranjarem excelentes colocações, amizade com pessoas poderosas e nomes conhecidos não apenas por se ligarem a famílias conhecidas, mas por seus méritos pessoais: Carlos lembra um "príncipe da Renascença”, por sua beleza e elegância; e Ega é o "Mefistófeles de Celorico", por sua verve contestadora e irônica, um verdadeiro dândi lisboeta.

Assim, o gesto de publicar um livro deve ser encarado de modo diferente, dependendo de quem o realize. Não tem o mesmo significado social uma publicação de Artur e uma de Carlos da Maia ou João da Ega. Estes últimos não podem dar-se ao luxo de cometer os mesmos erros que o jovem provinciano. Todas as atenções estão voltadas para eles, todas as expectativas são de que eles triunfem magistralmente, portanto qualquer coisa que seja menor que a glória já é uma derrota. Prova disso é a maneira como foi recebida a atuação de Carlos como médico:

\footnotetext{
Tinha visitas no consultório - ordinariamente bacharéis, seus contemporâneos, que sabendo-o rico o consideravam gratuito [...] E enfim (mas esta consagração não a esperava realmente Carlos tão cedo) alguns dos seus bons colegas, que até aí, vendo-o só a governar os seus cavalos ingleses, falavam do "talento do Maia" - agora, percebendo-lhe estas migalhas de clientela, começavam a dizer "que o Maia era um asno" (QueIRós, 1945a, p. 165).
}

Vê-se que a inveja e o despeito para com a riqueza e o luxo de Carlos, que causava tanta admiração em Lisboa, sempre conduzirá àquelas pessoas que julgarem o comportamento do jovem Maia a serem mais rigorosas com ele do que seriam com os demais, a cobrar mais dele, por se esperar, quase que 
"naturalmente", mais. Não é sem ironia que o narrador coloca a crítica na boca dos mesmos que antes admiravam seu estilo de vida; são seus "bons colegas", como diz o texto, que se decepcionam com a pouca clientela do médico. Embora não seja raro que um profissional liberal, no início de sua carreira, tenha poucos clientes, isso não é socialmente permitido a um Maia: ele deve triunfar sobejamente em tudo e de imediato, se quiser corresponder à imagem que dele fizeram os que sempre o viram envolvido em tanta elegância, luxo e dinheiro. Só faria sentido para a sociedade lisboeta, que tanto valorizava o ócio e o luxo aristocráticos, que Carlos deixasse de lado os prazeres de sua posição - ainda que apenas por algumas horas - se o fizesse para conquistar muito poder ou muito dinheiro. Nada disso ocorre, porém.

Carlos foi o primeiro de sua família a ganhar dinheiro mediante o seu trabalho, mas não é louvado por isso na tacanha Lisboa, e, sim, censurado. Ele trabalha, mas não fica mais rico e nem conquista poder político. "Para quê, então?": certamente perguntavam-se os que viam o jovem a cochilar, em seu luxuoso consultório. O padrão social, o que se esperava de alguém em sua posição, é o ócio e não o trabalho. Não se concebe alguém tão rico e prestigiado passar por dificuldades em um início de carreira.

Assim, Carlos da Maia e João da Ega são obrigados ao sucesso; não se espera menos deles. E isso vale também para suas atuações no âmbito da escrita. Por suas capacidades, somadas às potencialidades que sua condição social favorecida lhes deu, não se pode exigir pouco deles. Ainda mais num país que tem tanta necessidade de gente capaz e bem formada, para o erguer de seu lamaçal: sendo governado por bacharéis ineptos que só conquistaram seus altos cargos graças à sua influência política; tendo como oficial superior da Instrução Pública um homem que pensava não existir literatura na Inglaterra (Os maias); cheio de doença e pobreza; com uma grande massa de analfabetos facilmente dominada por um clero em grande parte ultramontano e vil ( $O$ crime do padre Amaro); vítima de uma exploração descarada por parte das potências estrangeiras, etc. Num país em que a competência nada vale se vem desacompanhada de poder e fortuna; com tanta necessidade de gente talentosa a mandar (e já farto de gente talentosa a obedecer a superiores pouco destros), Carlos e Ega não apenas têm a "obrigação" de dar certo, mas a "missão" de mudar tal cenário.

A expectativa para obras por eles lançadas seria, portanto, enorme e capaz mesmo de esmagá-los, senão estivessem bem preparados para tanto. Pode-se 
argumentar, entretanto, que se ninguém produzia nada de bom, eles teriam sucesso seja lá com o que for que produzissem. Correto? Não! Afinal, se o país pouco produz, isso não significa que ele consuma apenas o que é nele produzido. Os livros estrangeiros fazem sucesso em Portugal, sobretudo os franceses. Carlos e Ega não estariam a concorrer apenas com seus conterrâneos e, por melhores e superiores que fossem, não tinham a "aura" de saber e refinamento que era atribuída a quase tudo que vinha de França.

Carlos e Ega já estão no topo da pirâmide social por seu nascimento, fortuna e tudo mais. Não precisam lutar para alcançarem uma posição privilegiada, como Artur Corvelo. Escrevendo, correm o risco de desempenharem mal a sua função e serem ridicularizados, já que se espera tanto deles. Além disso, a ideia de justificar seus privilégios por seus méritos é uma ideia oriunda dos países mais ricos e poderosos, mas que ainda não foi plenamente assimilada em Portugal. Se não fizerem nada, Ega e Carlos já serão reconhecidos e aceitos como valiosos membros da elite. Então, para que trabalhar? Aliás, justamente por não fazerem nada podem ser considerados membros dessa elite. Trabalhar, aqui, é rebaixar-se: é deixar de ser um respeitável homem de mando e passar a ser um subalterno, um necessitado. Como podem, assim, realizar seriamente algum tipo de trabalho? Não podem e por isso não passam de diletantes. Por isso sua escrita fica sempre inconclusa.

Ao escrever sobre o glorioso passado de sua família, Gonçalo estaria elevando-se social e politicamente; estaria chamando a atenção do seu partido para si e sua antiga e honrada tradição familiar. Assim, ele quer transformar-se num símbolo da tradição e das glórias passadas. A obra de arte que Gonçalo almeja criar, escrevendo, não é sua novela histórica, mas seu próprio nome. Ela é só um instrumento mediante o qual ele poderá associar seu nome a toda carga simbólica que deseja. Sua narrativa pretende colocar novamente na ordem do dia o valor histórico dos Ramires, valorizando, assim, o último deles - o próprio Gonçalo - e este é o único tipo de trabalho que se aceita e mesmo se espera de um aristocrata.

É bem verdade que a simples escrita já facilitaria o acesso ao Parlamento, ainda que não se tratasse de uma obra histórica. Há muitos testemunhos históricos e ficcionais de escritores que atuaram no interior do Estado. O próprio Artur usa disso para se gabar da proximidade com os membros do poder, após retornar a Oliveira de Azeméis. Uma obra como a de 
Gonçalo, porém, permite ainda mais. Ela não apenas resgata a glória de um Portugal já muito distante e saudoso, como eleva o próprio autor, fazendo dele uma espécie de representante último destes tempos.

Bourdieu (1996) afirma que é preciso para os artistas inovadores produzir, além de sua obra, um público próprio. Ou seja, faz-se necessário produzir a demanda pela novidade que se está oferecendo ao público. O sociólogo francês apenas aplica especificamente para a arte um princípio que Marx formulou como válido para toda a economia moderna: para ele, o capitalismo está incessantemente a criar demandas por novos produtos, a sugerir necessidades até então desconhecidas. A respeito da arte, Bourdieu (1996, p. 289) sintetiza sua argumentação no seguinte trecho: "na ordem da produção, as práticas dos escritores e dos artistas, a começar por suas obras, são o produto do encontro de duas histórias, a da produção da posição ocupada e a da produção das disposições de seus ocupantes”. Assim, é preciso produzir a necessidade da obra, seu sentido, seu público.

O que Gonçalo pretende fazer com sua novela histórica é algo parecido: produzir a necessidade política de si mesmo; produzir nos círculos partidários e estatais a demanda por um tão digno representante da mais antiga aristocracia e dos tempos heroicos de Portugal. Ele quer "vender" sua imagem como nobre e patriota para conseguir uma indicação para concorrer como deputado. Deste modo, o próprio Gonçalo quer ser a materialização de um símbolo, mas para os símbolos causarem efeito eles devem ser conhecidos e reconhecidos como tal. A força do símbolo está em quão visceral ele consegue ser, em sua capacidade de obliterar a artificialidade que o compõe e apresentar-se como necessário; é a naturalização da História que lhe dá poder e ela só pode vir da crença coletiva, da generalidade e da coerção que seu uso apresenta, enquanto fato social, na definição durkheiminiana (DurkheIM, 2007).

Gonçalo pretende, pois, simbolizar toda uma realidade que a ele se liga pelo passado de sua família, por mais distante que esteja de sua verdade pessoal atual. Assim, a escrita de Gonçalo deve ser encarada de um modo completamente diferente daquelas já analisadas em Artur Corvelo ou Carlos da Maia e João da Ega. Para o fidalgo da Casa de Ramires, a escrita é mero instrumento de poder e jamais um fim em si mesmo. Gonçalo não pretende produzir uma obra com virtudes artísticas, mas ganhar poder político. Por isso, ele não hesita em adotar um procedimento de consulta que se aproxima do 
plágio e até mesmo planeja desde o início da narrativa a composição de outras obras que lhe trariam respeitabilidade e influência política:

Apareceria pois nos Anais com a sua Torre, revelando imaginação e um saber rico. Depois, trepando da Invenção para o terreno mais respeitável da Erudição, daria um estudo (que até lhe lembrara no comboio, ao voltar de Lisboa!) sobre as "Origens Visigóticas do Direito Público em Portugal..." Oh, nada conhecia, é certo, dessas Origens, desses Visigodos. Mas, com a bela História da Administração Pública em Portugal que lhe emprestara o Castanheiro, comporia corrediamente um resumo elegante... Depois, saltando da Erudição às Ciências Sociais e Pedagógicas - por que não amassaria uma boa "Reforma do Ensino Jurídico em Portugal” em dois artigos maçudos, de Homem de Estado?... Assim avançava, bem chegado aos Regeneradores, construindo e cinzelando o seu pedestal literário, até que os Regeneradores voltassem ao Ministério, e no muro se escancarasse a desejada porta triunfal. - E no meio do quarto, em ceroulas, com as mãos nas ilhargas, Gonçalo Mendes Ramires concluiu pela necessidade de apressar a sua Novela (QueIRós, 1999, p. 98-99).

Deste modo, as exigências que pendem sobre Gonçalo são bem distintas das que condicionam João da Ega e Carlos da Maia, embora todos os três fossem aristocratas e Gonçalo, ainda mais que os outros, um fidalgo da mais antiga estirpe nacional. A escrita da novela histórica de Gonçalo não precisa ter valor artístico. Se o tiver, melhor ainda, mas não se exige isso dela. O que se espera é que eleve o nome dos Ramires e narre seus feitos gloriosos. Mesmo o desejo de Gonçalo de aventurar-se por obras que misturam historiografia e direito ou pedagogia e direito demonstram que o tipo de respeitabilidade que ele almeja alcançar é a de "homem de Estado", como o trecho citado afirma, e não de artista. Ao contrário, "pinceladas" demais podem comprometer toda a obra. Ou seja, o uso de recursos estilísticos próprios de artistas pode prejudicar a verossimilhança da obra, diminuindo-lhe o valor, como fica patente na censura de Eça de Queirós a seu amigo Oliveira Martins numa carta de 26 de abril de 1894 (QueIRós, 1983, p. 311-315).

Gonçalo não quer ser um Eça, mas um Oliveira Martins. Não quer passar a vida a produzir obras que o façam respeitável como artista, mas uma chance de participar do Estado, como o próprio Oliveira Martins teve. O que os partidos Histórico e Regenerador esperavam de um deputado de uma pequena localidade sem importância além de fidelidade aos seus líderes políticos e capacidade de angariar os votos locais? Nada mais. Assim, não se exigia de Gonçalo mais que a postura de um sério e competente homem de Estado e isso, 
definitivamente, não passa por requintes de estilo literário e sensibilidade artística. A obra de Gonçalo deve antes de tudo provar patriotismo e erudição histórica: é o que basta.

Além disso, Gonçalo nunca fora um elegante. Quando ele, uma vez eleito, começa a ser conhecido e retratado pelos jornais de Lisboa, seu amigo Gouveia censura esse sucesso no High-Life, dizendo que Gonçalo "Desandou em janota!" (QueIrós, 1999, p. 443). O que prova que ele nunca antes dera motivo para ser visto como um homem elegante e chique. Gouveia vê com maus olhos esta repercussão dos atos da vida pessoal de Gonçalo por saber que, embora alguém possa ser deputado e janota, o poder maior está reservado aos mais sisudos, sérios e austeros políticos; ou ao menos aos que pareçam sê-lo.

Gonçalo, como Artur, não tem nada a perder ao iniciar sua novela histórica; mais que isso: como o jovem Corvelo é impelido pela necessidade e esta, pelo que se depreende dos enredos dos três livros, é melhor estímulo para o trabalho que a fartura e a boa-vida. O Fidalgo da Torre coloca a escrita a serviço dos seus interesses sociais, econômicos e políticos, ao invés de contrariá-los, como fizeram as outras três personagens. Por isso Gonçalo é o único que consegue o sucesso almejado e vai ainda além: percebendo que ser deputado era um sonho pequeno, vai ser colonizador em África.

\section{As três estratégias de classe a partir da escrita}

A comparação das personagens permite analisar melhor como os fatores sociais influenciaram cada uma e quais alternativas elas poderiam ter experimentado se suas opções tivessem sido distintas. Afinal, em cada uma das três obras se apresenta uma trajetória de desenvolvimento da escrita específica; a saber: A Capital! apresenta uma personagem cuja atividade de escrita vai contra seus interesses de classe e demais condicionamentos sociais e acaba por fracassar imensamente; Os maias apresenta duas personagens que a princípio optam por uma atividade de escrita que também vai contra seus interesses de classe, mas que acabam desistindo, não concretizando-a e mantendo-se na mesma posição social, se bem que um pouco frustrados e levemente desacreditados; já A ilustre casa de Ramires apresenta uma personagem que coloca a escrita na direção de seus objetivos políticos e interesses de classe, alcançando, assim, o sucesso almejado e indo mesmo além dele. 
Há algumas semelhanças entres os três, entretanto. Pode-se associar, por exemplo, a admiração que Carlos e Ega cultivam por tudo que vem dos países ricos da Europa, notadamente França e Inglaterra, com a admiração de Artur para com tudo que ele imagina ligar-se a Lisboa, em oposição aos gostos e hábitos provincianos. Lisboa que ele chega a equiparar com a Paris dos livros românticos que leu. Fica evidente, na leitura d'Os maias, que essa admiração pelo estrangeiro não se limita aos dois jovens. Aliás, o famoso texto de Eça sobre a influência francesa em Portugal "O francesismo" demonstra como essa questão se apresentava como geral, consolidada e já antiga em todo o país. Porém, diante do argumento, de que Carlos e Ega não admiram os países ricos com mais ardor que seus demais contemporâneos existe uma defesa muito simples: tampouco Artur admira mais a Lisboa que os demais provincianos. Fica claro isso em todo o livro, desde o começo da narrativa ainda na estação de Ovar até o retorno quase que triunfal de Artur a Oliveira de Azeméis, onde as suas histórias sobre a capital causam enorme alvoroço, a princípio.

Assim, existe uma similitude entre Artur, Ega e Carlos. Sem dúvida essa comparação não pode ser feita em matéria de dinheiro e tradição, mas será que não se pode associar em elegância, prestígio intelectual e refinamento o Artur que volta triunfante para Oliveira de Azeméis com Carlos da Maia em seu auge? Aos olhos da pequena localidade, Artur não representaria, no tocante a estes aspectos, o mesmo que Carlos representava para Lisboa? Provavelmente, sim.

Não se trata, evidentemente, de uma diferença tão somente de grau, como se Artur fosse um Carlos da Maia "em miniatura", ou destinado a públicos menos exigentes. Essa comparação não pode esquecer que Artur é alguém que contou com a ajuda da sorte (recebendo uma gorda herança), enquanto Carlos é alguém que descende de uma sólida família aristocrata e rica de Lisboa. Outro fator permite ainda continuar esta comparação: Artur, ao voltar para Oliveira de Azeméis, transforma-se no portador de novidades da civilização "superior" lisboeta. Esse caráter de contato com o novo está também claramente presente em Carlos da Maia e João da Ega. Em Lisboa, eles são vistos como portadores de novidades: novos conhecimentos; hábitos das grandes capitas europeias ainda desconhecidos em Portugal; gosto moderno, dispensando as formas de arte já ultrapassadas, etc. 
A diferença maior, entretanto, é que Carlos e Ega arriscam-se menos. Eles não comprometem suas fortunas e tentam não comprometer seus nomes e seu prestígio, ao acabarem por procrastinar as publicações planejadas. Procrastinar constantemente até chegarem a desistir verdadeiramente de publicar qualquer coisa. Eles estão cientes de como a sociedade lisboeta é tacanha (assim como Artur estava ciente dos limites de Oliveira de Azeméis). A comparação, portanto, não deve ser feita entre os atos dos dois aristocratas e os do Artur recém-chegado em Lisboa, mas, sim, entre os atos destes e os do Artur que regressa à Oliveira de Azeméis.

Ao regressar, Artur mostra-se ciente das características do local em que se encontra e contenta-se em voltar a ser ajudante de farmácia. Deste modo, não se arriscaria mais a perder seu capital econômico, numa nova ida a Lisboa ou numa vida de luxo provinciano em Oliveira de Azeméis. Deste modo, ele é tão conservador na escolha de suas estratégias na luta de classes quando em um ambiente conhecido quanto Carlos e Ega. Pode-se argumentar que ele foi bastante ousado ao publicar seu pasquim, mas um argumento existe para sustentar ainda a ideia anterior: vindo de Coimbra e acostumado aos constantes protestos estudantis, iludido ainda quanto ao poder das Letras, Artur não conhecia profundamente o tacanho ambiente de Oliveira de Azeméis. Por mais que já estivesse lá há algum tempo, sua ingenuidade faz com que ele analise a pequena localidade segundo os padrões com que se acostumara na Lusa Atenas. Há que se lembrar de que sua educação foi feita mais em função de leituras ultrarromânticas que em sintonia com a realidade. Além disso, ele teve antepassados que viveram em Lisboa e se dispersaram na província por causa da guerra civil e não por vontade própria (Queırós, 1992, p. 99). O que reforça a ideia de que não estava ele habituado ao pensamento extremamente conservador de Oliveira de Azeméis. Nascera ele em Ovar, que, se não é nenhuma capital europeia, é maior e mais importante que o local em que residirá com as tias. Além disso, morara e estudara em Coimbra.

Se, ainda assim, insistir-se em pensar que o ambiente da cidadezinha não lhe era estranho, deve-se ao menos reconhecer que, ao retornar à Oliveira de Azeméis, após as desilusões de Lisboa, Artur mostra-se tão conservador quanto Carlos e Ega, se não mais. Ele se perde em devaneios e fantasias quando em contato com uma realidade que julga superior à sua. Todavia não se pode acusar a família Maia do mesmo exagero em sua admiração pela realidade 
social estrangeira? Provavelmente, sim. Afinal, Afonso, em sua juventude, deixa de lado os ideais liberais para gozar dos prazeres e requintes da vida na Inglaterra, e seu neto abandonará os ideais de regenerar Portugal e de ser útil ao país ao se transferir definitivamente para Paris, vivendo apenas para gozar a vida e considerando sua futilidade no requintado e luxuoso ambiente parisiense da vida suprema que alguém poderia levar.

Gonçalo difere de Artur Corvelo, Carlos da Maia e João da Ega quanto a esta admiração por ambientes superiores de cultura e civilização. Ele deseja ser deputado e ir para Lisboa, mas não por admirar enormemente esta cidade. Gonçalo é bem mais pragmático e realista que as demais personagens aqui citadas. Ele deseja o poder, ser admirado e ter dinheiro, mas não se deixa encantar pelas aparências, indo direto até aquilo que ele pensa ser realmente capaz de o dignificar. Ao menos, é assim com o novo Gonçalo, que emerge do sonho com os avoengos e do combate contra Ernesto de Nacejas.

Mesmo depois de eleito deputado, Gonçalo não se deixa encantar pelas glórias de seu triunfo, mas se porta de modo bem realista, afastando-se das ilusões que um novato no Legislativo poderia cultivar. Aliás, antes de empossado deputado, ele já vislumbrara a mesquinhez desse cargo em vista da posição de mando que sempre almejou. Antes de ir a Lisboa, ele já decide que esse mandato será apenas um degrau em direção a algo maior.

Essa percepção realista do mundo faz Gonçalo ser mais eficiente em suas estratégias de poder. Ele é o único que enfrenta a mediocridade com mediocridade - resolvendo fazer uma novela baseada na desconhecida obra de um parente obscuro. Por se dispor a fazer algo concatenado com a realidade que percebe - de políticos que fazem carreira a partir de obras vazias de verdadeira criatividade -, Gonçalo acaba por superar-se e realmente fazer algo bom (senão sua novela, ao menos sua transformação).

A personagem se envolve cada vez mais com o processo de produção literária, passando a não seguir fielmente a narrativa do tio Duarte e acrescentando, assim, algo de seu à diegese. Com isso, descobre-se em relação com o passado de sua família e acaba por despertar em si a valentia que tanto admirava nos avoengos e que tanto desejara imitar. Não parte Gonçalo do sublime, mas da medíocre realidade que o cercava e da qual ele fazia parte. É por querer partir do possível que ele se supera e acaba por conseguir mais do que jamais sonhara. 
Carlos e Ega, diferentemente de Gonçalo, desejam partir do pressuposto de que são superiores a todos os demais, melhores que todo o resto do país. Assim, suas obras deveriam obrigatoriamente apresentar-se como a expressão de gênios superiores, granjeando sucesso de público e crítica. Como este sucesso não podia ser de antemão garantido, essa ambição desmedida e a presunção que a acompanha acabam por intimidar aos dois jovens, que permanecem estéreis em sua escrita.

Publicar é arriscar; é submeter-se a ter seu trabalho julgado por seus pares e pelos leitores. O mercado literário não deixa de ser moldado, dentre outras coisas, por relações de classe. Assim, escrever é algo que coloca em atuação não apenas a criatividade e a dedicação do autor, bem como seus condicionamentos sociais e as estratégias que lhe são possíveis no âmbito da luta de classes. Publicar uma obra é um ato que se insere no contexto destas estratégias, podendo ser coerente com elas ou não. No caso de Gonçalo, vê-se esta coerência; nos dos demais, não.

No que se refere a Carlos e Ega, seguir as ideias estrangeiras é ir contra sua própria classe, seu próprio poder; no que diz respeito a Artur, gastar uma grande soma para lançar-se como artista também é ir contra sua classe (o pequeno-burguês é tipicamente sovina e "filisteu" em matéria de arte); Gonçalo é o único que realiza o que se espera dele, que atua na direção das forças sociais que o envolvem. Este realismo, essa percepção acertada da realidade social, faz com que suas estratégias de poder na luta de classes venham a ser muito mais efetivas que as das demais personagens. Ele não contraria as forças presentes no campo social, mas avalia bem como se aproveitar delas e insere-se nestes conflitos a partir de uma estratégia bem formulada e coerente.

Gonçalo busca uma recompensa exógena, externa ao campo literário: a vitória política. Carlos da Maia, João da Ega e Artur Corvelo buscam recompensas endógenas: sucesso no campo literário. Artur corre o risco até de perder suas vantagens no mundo extraliterário (dinheiro) por causa do sonho de se afirmar como escritor. Para Artur, Carlos e Ega, a literatura seria um fim em si mesmo, enquanto, para Gonçalo, mero instrumento de conquista do poder. Evidentemente, essa ideia de fim em si mesmo, de amar a literatura apenas pela literatura propriamente dita, merece algumas críticas e não pode ser absolutizada: é claro que Artur, Carlos e Ega desejavam também o prestígio que o sucesso literário poderia trazer-lhes; sobretudo Artur, 
evidentemente. Isso aparece-lhes como consequência intrínseca de seu amor pela arte enquanto arte ou pelo conhecimento enquanto conhecimento, porém. É o que se pode deduzir da obra de Bourdieu (1996), que tenta demonstrar como existe uma atitude ideológica de denegação dos valores materiais e das recompensas externas ao campo naqueles que almejam um sucesso longo e duradouro, ainda que tardio, por meio do acúmulo de prestígio (capital cultural).

A história da evolução do campo literário apresenta uma oposição entre os que veem a literatura como mero instrumento de difusão de ideias ou defesa de determinados valores e os que defendem a autonomia do campo. A obra de Bourdieu a respeito da gênese do campo literário é primordial para se entender isso. Deve-se ter em mente que nada existe como uma realidade em si, separado de tudo o mais, independente de causalidades e conexões externas. A autonomia do campo tende a "ofuscar", por meio da ideologia que afirma, os interesses materiais que subjazem às produções ligadas à "vida do espírito”. Eles jamais deixarão de existir, entretanto.

Assim, Gonçalo vê a literatura como intermediadora entre ele e o objeto de seu desejo: o poder político. Ele percebe o campo literário lusitano pouco desenvolvido e joga com isso; tenta tirar vantagem disso. Mas tampouco Artur Corvelo ou Carlos e Ega têm a arte ou o conhecimento como objeto de um amor exclusivo. Para o jovem de Oliveira de Azeméis, a arte deve ser fonte de reconhecimento e admiração alheia. Constitui-se simplesmente um caminho de ascensão social e foi assim durante toda a sua vida. Foi com esse intuito que seu pai o incentivou a cultivar seu interesse pelas letras. Quanto a Carlos e Ega, seu apreço pela literatura e pela escrita acadêmica não é maior que seu apreço por si próprios. Eles desejam impor-se enquanto pessoas dignas de prestígio, superiores aos demais de seu país, e renunciam à produção escrita justamente para não arriscarem manchar essa posição dominante com algum fracasso vexatório. Assim, o amor à posição de aristocratas (tidos por cultos, inteligentes e elegantes) é maior que o amor à escrita e à literatura em si. Serão, por conseguinte, sempre diletantes.

Nenhum dos quatro, portanto, deve ser visto como alguém que ame a literatura profundamente, a ponto de buscá-la pelo próprio interesse que ela desperte. Trata-se de escritores, ou proto-escritores, que não amam o processo de produção escrita. Para Gonçalo, escrever é um martírio: ele tem de se 
policiar para poder continuar a escrever, a despeito de sua preguiça e desinteresse. Para Carlos e Ega é algo sempre adiado; deixado de lado em prol de prazeres e luxos mundanos: tais como relações adúlteras, a esgrima, passeios, ceias em restaurantes diversos, bilhar, conversas, etc. Quanto a Artur, seu apreço pela escrita liga-se diretamente à busca por recompensas sociais, tais como dinheiro e fama; é por isso que, em Oliveira de Azeméis, ele só passa a escrever com afinco quando a ideia dada por Rabecaz (escrever um drama) inspira-lhe confiança no sucesso. Além disso, uma vez de posse da herança do padrinho, pouco trabalha; dedicando-se mais ao ócio que à produção de novos textos ou a revisão dos já existentes. Se a escrita lhe desse real prazer, aproveitaria do dinheiro para, uma vez livre do trabalho na botica, escrever muito mais. Isso, porém, não acontece.

Pode-se perceber que a literatura é para Gonçalo um mero instrumento para alcançar notoriedade e respeito no meio partidário e, assim, conseguir fazer deslanchar sua carreira como político. Tampouco Gonçalo deseja o poder político em si; ele quer, como Artur, dinheiro e admiração alheia. O poder também é um mero instrumento para ele. Ao menos é assim até o sonho com os avoengos, que o levará a uma profunda transformação, consumada no dia seguinte perante Ernesto de Nacejas. Prova disso é que, assim que não sente mais necessidade dessa aceitação alheia, o Fidalgo da Torre deixa de lado seus planos de chegar a ministro.

Assim, ele percebe que a política não é, verdadeiramente, o que ele primariamente desejava, mas, sim, a aprovação das outras pessoas. Uma vez livre dessa necessidade contumaz de aceitação, Gonçalo parte em direção a algo que realmente o faça grande diante de seus próprios olhos; a despeito das censuras e recriminações de quem acha temerária tal empreitada. A princípio, portanto, a literatura é, para ele, de uma importância secundária, já que se constitui num artifício para se alcançar uma posição política que, por sua vez, é ela também um instrumento de ascensão social, que visa colocar Gonçalo mais próximo da dignidade herdada de sua família e trazer o respeito e a veneração dos que o cercam. Assim, ela é um instrumento de segunda ordem para o Fidalgo da Torre, enquanto constitui-se em um de primeira ordem para Carlos da Maia, João da Ega e Artur Corvelo.

Esta instrumentalização da literatura liga-se às opções que cada personagem faz no conflito permanente que existe em uma sociedade dividida em classes. Tudo se torna arma na tentativa de sobrepujar os demais, num 
contexto de individualismo crescente e consolidação do capitalismo em Portugal. A atuação no campo da produção da escrita não pode ser vista como desconectada do resto do mundo, mas tem um importante papel na disputa entre burgueses e aristocratas, por todo o século xIx; como terá por todo o século xx na disputa entre burgueses e proletários, produzindo uma ampla gama de livros tidos como "de esquerda", ou ligados à causa proletária e à denúncia das injustiças sociais. Segundo Bittencourt (2010, p. 1): "A história do romance intercruza, assim, a história da burguesia, da produção e do consumo de arte voltados para ela”.

Não é algo novo o uso da escrita para promover a disseminação de ideologias e doutrinas. O judaísmo, o islamismo e o cristianismo já fizeram isso. O livro sempre serviu para as mais diversas batalhas políticas, religiosas, econômicas e sociais. Sem falar em questões puramente pessoais. O próprio João da Ega planejou escrever $O$ lodaçal, como uma vingança pessoal contra os que o ultrajaram. Como disse Aristóteles, o homem é um ser político e seria de se estranhar não o fato de ele usar da escrita para fazer política, mas se não o fizesse.

Assim, toda obra escrita é portadora de significados políticos. A simples escolha do tema a ser trabalhado, o estilo, o gênero e a linguagem já são escolhas que carregam em si aspectos políticos. Há uma grande diferença entre uma obra escrita sobre um tema já consagrado, com estilo corriqueiramente valorizado, linguagem padrão e no gênero mais aceito e uma obra sobre um tema polêmico, em estilo inovador, linguagem considerada indesejável e num gênero tido como "menor”. A primeira será talvez um clássico ou uma imitação de um clássico; a segunda será tida como desprezível ou valorizada como revolucionária. Isso implica uma escolha de posição nas disputas internas do campo literário e, como estas disputas estão necessariamente imbricadas com estratégias dentro da luta de classes, tornam-se conflitos políticos.

A particularidade deste artigo está no fato de que ele pretende analisar a figuração política também dos livros abortados, o aspecto político que subjaz à escolha de não terminá-los ou sequer iniciá-los. Carlos e Ega optam por não continuar seus projetos de escrita literária (os três livros de Ega); de crítica artística, política e social (a Revista de Portugal); e científica (livro de Carlos). Trata-se de uma opção; ainda que inconsciente ou não explicitada. Opção muito coerente, aliás, com sua condição de classe e o momento histórico porque passava Portugal na época. Para eles, 
aristocratas ricos e bem estabelecidos, escrever, num mercado cada vez mais capitalista e competitivo, seria correr um risco desnecessário. Assim, eles não apenas acabam por deixar de lado a ideia de escrever seus livros e sua revista, bem como toda e qualquer ideia de intervir na realidade social para mudar o país.

Não é por mera coincidência que a renúncia à escrita venha ao lado da renúncia em acreditar no país e em tentar salvá-lo. As duas têm o mesmo motivo: são fruto da percepção, talvez inconsciente, que sua própria condição de privilegiados constituía-se como um dos entraves ao desenvolvimento e modernização de Portugal. Mesmo João da Ega, tão iconoclasta e contestador desde os tempos de Coimbra, acaba por confessar a si e a seu mais íntimo amigo essa percepção: "Nasceste - acudiu o Ega - para colher as flores dessa planta da civilização, que a multidão rega com o seu suor! No fundo também eu, menino!" (QueIrós, 1945b, p. 234-235). Por mais ironia que haja nesta fala, ela não deixa de explicitar, numa espécie de ato falho freudiano, a incômoda percepção de que eles não passavam de parasitas sociais. Trata-se do inconsciente revelando-se em meio ao disfarce da ironia e da verve.

Assim, privilegiados, estabelecidos, cheios de riqueza e prestígio, os jovens não encontram motivo para arriscar suas imagens de sucesso em uma empreitada incerta. Concorrer com o burguês é dignificá-lo, tratá-lo como um igual, aceitar que ele também tem valor; abster-se de concorrer - numa atitude de desprezo soberbo em relação a tudo que não provém de si ou de sua classe - apresenta-se como um ato de superioridade.

Narcisistas, Carlos da Maia e Ega menosprezam tudo que os cerca, autoproclamando-se a fina flor da sociedade portuguesa. Essa postura é tipicamente aristocrata e diferencia-se pouco daquela adotada por outros nobres durante os séculos anteriores. Por mais que permeados de ideias novas e modernas - vindas da França, sobretudo -, os dois jovens ainda se comportam como herdeiros da tradição do Antigo Regime. São pouco distintos dos seus antepassados. Afinal, mesmo sua adesão às ideias modernas não deixa de ser um traço típico de sua classe: sempre foi característica da aristocracia o cosmopolitismo e um apego maior às elites dos outros países que às próprias classes inferiores de seu próprio povo. Os aristocratas europeus sempre foram internacionalistas e não é à toa que a Revolução Francesa, enquanto movimento comandado pela burguesia, defendeu o nacionalismo como necessária arma de transformação social e abolição do Antigo Regime. A Santa 
Aliança era internacionalista e fazia da união dos interesses da nobreza a fonte de sua atuação.

Já Artur Corvelo, na tentativa de ser amado e respeitado, busca o sucesso literário, desejando fama e dinheiro. A busca por esse sucesso se coloca, para ele, acima de sua própria condição de classe. Assim, ele chega a comprometer, em parte, essa posição; em busca deste sucesso. Artur é antes um escritor iniciante que um pequeno-burguês, na medida em que sua prioridade não é a manutenção de sua posição de classe, mas sua carreira - ao menos de início, antes de suas desilusões com Lisboa e com a vida de escritor. Carlos da Maia, João da Ega e Gonçalo Mendes Ramires não. Eles colocam em primeiro lugar sua posição social, deixando em segundo plano a escrita.

Como a escrita vai ao encontro das aspirações de classe de Gonçalo, ele a torna efetiva e produtiva, mesmo que a duras penas. Como ela vai de encontro às aspirações de classe de João da Ega e Carlos da Maia, eles acabam por não realizá-la, preferindo seguir a mesma linha de atuação de outros aristocratas contemporâneos e antepassados. Como já se salientou, o próprio Afonso nunca fez nada, nunca trabalhou. Ele pressiona o neto para que trabalhe, mas ele mesmo nunca deu o exemplo e, olhando por essa perspectiva, a admiração que muitos lhe dedicam - sobretudo Carlos - parece um pouco injustificada. Muito estudiosos têm insistido neste ponto, ressaltando o comodismo e os preconceitos de Afonso, mas talvez seja Maria Manuel Lisboa (2000) a mais crítica com relação a esta personagem, apresentando-o como falhado e culpado pelo incesto de seus netos.

Nos três livros, vê-se, portanto, estratégias pessoais de luta por poder que passam pela escrita. Ela é elemento de um todo maior - dessa disputa histórica, política, social e econômica chamada "vida em sociedade" - e só pode ser entendida a partir daí. O próprio conceito de "escrita" é social e, portanto, histórico. Carlos Reis, no III Encontro Internacional de Queirosianos, explicou a diferença entre autor, figura simbólica do texto (como descrito por Foucault), e escritor, figura social da instituição literária, como ele próprio coloca (REIS, 1997, p. 19).

Os três livros aqui analisados trazem diferentes aspectos dessa figura social institucionalizada, que é o escritor. Nos três percebem-se elementos de luta de classes permeando a escrita e a opção pela realização ou não da obra. Poderia ter-se optado, neste estudo, por uma ampla análise das personagens escritoras 
em Eça, passando também por Carlos Alcoforado, d'O crime do padre Amaro; Ernestinho Ledesma, d'O primo Basílio; e Tomás Alencar, d'Os maias. Isso não foi feito, entretanto, porque essas personagens apresentam-se como muito bem adaptadas ao que delas se espera no campo literário. São medíocres que alcançam um sucesso medíocre, mediante uma postura de aceitação convencional do papel que lhes é dado socialmente.

Tratando-se de personagens assim, é extremamente simples e fácil perceber os condicionamentos sociais de suas ações e a pertinência delas dentro do âmbito da luta de classes: Ernestinho altera o drama de acordo com as exigências do empresário, subserviente aos interesses econômicos; Tomás Alencar cultiva amizades com a aristocracia e a rica burguesia, buscando jamais ofender as sensibilidades daqueles que lhes servem de protetores. Assim, a malícia que ele coloca nos versos destinados a Raquel Cohen deve ser bem sutil (“Abril chegou! Sê minha”), uma vez que os interesses de classe falam mais alto que seu desejo de liberdade criativa. Quanto a Carlos Alcoforado, é apenas uma breve figura, toda caricatural, retratada de um modo que demonstra uma sujeição plena ao estereótipo.

No seio da análise dessas quatro personagens, entretanto, outras personagens escritoras foram analisadas brevemente, traçando assim um quadro mais amplo do tema da literatura dentro da ficção queirosiana. É o caso do Roma, do Castanheiro e do próprio Tomás Alencar. Nenhuma delas, entretanto, comporta a riqueza de análise que permite a comparação entre Carlos da Maia, João da Ega, Artur Corvelo e Gonçalo Mendes Ramires. Isto porque estas quatro personagens permitem que se trace uma oposição nítida entre adentrar-se no campo literário - como é o caso de Artur e Gonçalo - e renunciar a essa penetração, mesmo desejando-a ardentemente - caso de Carlos da Maia e João da Ega. Entrada e renúncia que são motivadas, em grande parte, por interesses de classe. Ambas carregam em si o aspecto de elemento constituinte de uma estratégia mais ampla; estratégia usada na luta de classes.

Dentre estas personagens, Artur Corvelo se afigura como meio-termo: é alguém que de fato publica, como Gonçalo, mas cuja atividade de escrita vai contra seus interesses de classe, como é o caso de Carlos e Ega. Além disso, seu fracasso serve de modelo para que possa ser pensado o que Carlos da Maia e João da Ega tanto temiam e que acaba por torná-los estéreis em matéria de produção no âmbito da arte e do saber. 
Outra figura queirosiana poderia ser elencada aqui e não o foi: Carlos Fradique Mendes. Rico e cheio de prestígio, sua posição social se assemelha muito à de Carlos e Ega, mas, diferentemente deles, Fradique não tem o intenso desejo de tornar-se um escritor, seja artístico, científico, político, social ou crítico. Os dois amigos estão o tempo todo a projetar suas obras e a cobrarem um ao outro a escrita de seus projetos particulares e o início de seu projeto comum: a revista. Já Fradique, após os textos satânicos da juventude, abandona a escrita (a não ser de suas cartas e nelas não aparece nenhum projeto de livro, artigo ou algo do gênero).

Fradique diz não acreditar na capacidade da palavra de traduzir verdadeiramente os sentimentos, as ideias e mesmo a mais banal realidade existente. A despeito do que ele disse, porém, mais elementos poderiam ser acrescentados a esta escolha por nada publicar, tornando a questão mais complexa. Os motivos que levam Carlos da Maia e João da Ega a não escrever, no entanto, poderiam muito bem ser estendidos também a ele, se houvesse a manifestação por parte do "último Fradique" de algum desejo de tornar-se escritor de qualquer tipo de obra. Este desejo não existe, porém, e é Eça que o transforma num, ao publicar suas cartas, após sua morte.

Assim, os motivos determinantes para se entender a opção de Fradique estão mais ligados às limitações da linguagem e a um afã filosófico de busca exigente pelo real que por alguma estratégia de luta de classes, se bem que não necessariamente destoante dela. Toda a caracterização da personalidade dessa figura queirosiana conflui para uma posição de autoconfiança e autonomia, porém, não autoriza uma leitura de renúncia à escrita por medo do fracasso, como ocorre com Carlos e Ega. De modo que a tentativa de atribuir uma motivação social para sua escolha de não continuar a escrever seria como tentar adaptar o texto ficcional à hipótese aqui lançada e não o oposto. Nem todo homem inteligente deseja ou é obrigado a desejar tornar-se escritor. Eça, em sua atitude criativa, ressente-se de que Fradique não tenha desejado seguir esta carreira. A crítica não pode se deixar iludir pela astúcia e sedução queirosianas e acabar por comungar deste lamento. A capacidade intelectual, o talento, o gosto, o refinamento e a experiência de mundo de Fradique são notáveis e poderiam fazer dele um excelente escritor. É isso que Eça nos leva a pensar. É preciso tomar cuidado, porém, para não se deixar levar pelas artimanhas do autor e acabar por partilhar 
deste seu desejo frustrado de que Fradique tivesse optado por ser escritor. Ele não demonstrou querê-lo e o maior mérito de Eça quanto a esta figura ficcional é fazer com que não aceitemos essa sua escolha, como ele próprio - seu criador - fingia não aceitar.

\section{Referências}

Bittencourt, Rodrigo do Prado. Aspectos históricos e sociais da formação do romance em países da periferia do capitalismo. LL fournal, v. 5, n. 2, p. 1-5, 2010. Disponível em: <https://ljournal.commons.gc.cuny.edu/2010-2-doprado-texto/>. Acesso em: 6 jan. 2017.

Bourdieu, Pierre. As regras da arte. Gênese do campo literário. São Paulo: Companhia das Letras, 1996.

Durkheim, Émile. As regras do método sociológico. São Paulo: Martins Fontes, 2007.

LisboA, Maria Manuel. Teu amor fez de mim um lago triste: ensaios sobre "Os Maias" Porto: Campo das Letras, 2000.

Lopes, Ana Cristina; ReIs, Carlos. Dicionário de narratologia. Coimbra, Almedina, 2000.

Martins, António Coimbra. Ensaios queirosianos. Lisboa: Europa-América, 1967.

QueIrós, José Maria Eça de. Os Maias: episódios da vida romântica. Porto: Lello e Irmão, 1945a, v. 1.

QueIrós, José Maria Eça de. Os Maias: episódios da vida romântica. Porto: Lello e Irmão, 1945b, v. 2.

Queirós, José Maria Eça de. Carta a Oliveira Martins. Paris, 26/04/1984. In: Queirós, José Maria Eça de. Correspondência. Lisboa: Imprensa Nacional - Casa da Moeda, 1983, v. 2, p. 311315.

QueIrós, José Maria Eça de. A Capital! (começos de uma carreira). Lisboa: Imprensa nacional Casa da Moeda, 1992.

Queirós, José Maria Eça de. A ilustre casa de Ramires. Lisboa, Imprensa nacional - Casa da Moeda, 1999.

Queirós, José Maria Eça de. O crime do Padre Amaro. Lisboa: Imprensa nacional - Casa da Moeda, 2000.

Reis, Carlos. Eça de Queirós e a literatura como ficção. In: Miné, Elza; Caniato, Benilde (Ed.). 150 anos com Eça de Queirós. III Encontro Internacional de Queirosianos. São Paulo: CEP, 1997, p. $17-28$.

RoBert, Marthe. Romance das origens, origens do romance. Lisboa: Via, 1979.

Recebido em 19 de fevereiro de 2017.

Aprovado em 22 de abril de 2017. 


\section{Resumo/Abstract/Resumen}

\section{Eça de Queirós: mercado literário e classe social}

Rodrigo do Prado Bittencourt

Este artigo tem por objetivo investigar a relação entre a escrita e classe social na vida de quatro personagens de três livros de Eça de Queirós: Artur Corvelo, de A Capital! (começos duma carreira); Carlos da Maia e João da Ega, de Os Maias: episódios da vida romântica; e Gonçalo Mendes Ramires, de A ilustre casa de Ramires. Assim, faz-se necessário conhecer o "campo literário" (BouRdiEu, 1996) português da segunda metade do século XIX para melhor entender as influências condicionantes que pesavam sobre o escritor iniciante.

Palavras-Chave: Eça de Queirós, mercado editorial, personagens, classe social, escrita.

\section{Eça de Queirós: literary market and social class}

Rodrigo do Prado Bittencourt

This paper examines the relationship between writing and social class in the lives of different characters from three books by José Maria Eça de Queirós: Artur Corvelo, from $A$ Capital! (começos duma carreira); Carlos da Maia e João da Ega, from Os Maias: episódios da vida romântica; and Gonçalo Mendes Ramires, from A ilustre casa de Ramires. For a better understanding, it is necessary to explore the concept of "literary field" (Bourdieu, 1996) of Portugal during the second half of the $19^{\text {th }}$ century and consider the constrictions endured by the novice writer at this time.

Keywords: Eça de Queirós, editorial market, characters, social class, writing.

\section{Eça de Queirós: mercado literario y clase social}

\section{Rodrigo do Prado Bittencourt}

Este artículo tiene como objetivo investigar la relación entre escritura y clase social en la vida de cuatro personajes de tres libros de Eça de Queirós: Artur Corvelo, de A Capital! (começos duma carreira); Carlos da Maia y João da Ega, Os Maias: episódios da vida romântica; y Gonçalo Mendes Ramires, de A ilustre casa de Ramires. Por lo tanto, es necesario conocer el "campo literario" (Bourdieu, 1996) portugués de la segunda mitad del siglo XIX para comprender mejor las influencias condicionantes que pesaban sobre el escritor principiante.

Palabras clave: Eça de Queirós, mercado editorial, personajes, clase social, escritura. 